\title{
A critical view on the mainstream theory of economic cycles
}

\author{
Radu ISAIC \\ University of Economic Studies, Bucharest, Romania \\ isaicradu@yahoo.com \\ Tudor SMIRNA \\ University of Economic Studies, Bucharest, Romania \\ tudorsmirna@gmail.com \\ Cristian PAUN \\ University of Economic Studies, Bucharest, Romania \\ cristian.paun@rei.ase.ro
}

\begin{abstract}
World economy is frequently affected by fluctuations that occur recurrently with a certain periodicity. The predictability of economic fluctuations is low. Frequency and magnitude of cycles is generally reduced. Economy cycles belong to the economy's DNA. It is measured by different indicators, but the most important is GDP. There are four types of economic cycles: Kitchin (Stocks), Juglar (Investment), Kuznets (Infrastructure), Kondratiev (Technological Innovation). Right now, science and technology are going through major changes that lead to an economic crisis of the Kondratiev model. Fiscal and monetary policy can alleviate fluctuations. Theories explaining economic cycles: overinvestment (misallocation of rare resources), Keynesiana (insufficient aggregate demand), monetarist (lack of monetary discipline), real business cycle (aggregate supply in change), neo Keynesiana (market imperfections), consensus (all factors considered). The financial cycle has been little considered so far. The financial cycle greatly influences the economic cycle, finances allocate resources and creates purchasing power. The financial cycle has a different structure than the economic one. It can use fiscal and monetary policies to direct it. The only paradigm that links the economic and financial cycles is the Austrian economic paradigm. In practice and current economic theory, there is a desire for a coincidence in time between the phases of the economic cycles of the various state entities of the United States and a convergence of evolution towards the same qualitative and quantitative characteristics. This implies an identity of cultural, historical, economic, political, and psychological evolution of the EU, which can not be achieved even between close regions of the same national state. The lack of barriers to the circulation of economic information (goods, services) between regions will lead to an approximate coincidence of economic evolution, but starting from the psychic structure of the inhabitants of a region, the cultural, religious and cultural heritage passing through the capital, the economic zones differ and to force them in different directions will lead to unnecessary fragmentation lines. The anticipated outcome of the study: It is desirable to leave economic areas to evolve in their own terms rather than leveling and uniforming them by economic manipulation techniques. It is preferable to use the method of scientific abstraction and deductive apriorism during the study.
\end{abstract}

Keywords: economic cycles, crises, prices, wages, investments, money

Please cite the article as follows: Isaic, R, Smirna, T., Paun, C., (2019), "A critical view on the mainstream theory of economic cycles", Management \& Marketing. Challenges for the Knowledge Society, Vol. 14, No. 1, pp. 48-58. DOI: 10.2478/mmcks-2019-0004. 


\section{Introduction}

One of the great problems of the contemporary economy is the understanding and explanation of economic cycles. Pain and suffering created by one of the phases of the economic cycle - crises force us to try to understand what is at the root of the economic cycle and to try to alleviate the negative aspects of this difficult phenomenon to anticipate.

In the 19th century, there was no concrete and clear attempt to explain the periods of inflation and depression, stability and imbalance that marked this century. 19th Century economists were thinking long-term on issues of production, allocation, distribution in the assumption of total employment, but with the crisis of the third decade it was necessary to penetrate with explanation in the mechanism of economic fluctuations.

Capitalist countries' economy has grown unambiguously over the past two centuries, but growth has been far from being linear, steady at a fixed rate. There has been a steady fluctuation in productive capacity, occupancy, income, prices. The periods with high values of those elements alternated with periods with low values.

*A classification, in our view, of the theories of economic cycles, according to the causes:

A)Exogenous theories of economic cycles. The cause of the economic cycle originates outside the economic system:

1.Cycles due to natural resources and climate change. Exhaustion of resources in a certain area may lead to the disappearance of civilizations. Finding new resources can create major economic fluctuations.

2.Cycles due to demographic waves, changes in birth rate or migratory waves.

3.Cycles originated in erroneous political decisions. Unnecessary waste of resources, wars, etc.

4.Cycles due to technological innovations. Kitchin, Juglar, Kuznets, Kondratiev.

B)Endogenous theories of economic cycles. The cause of the economic cycle is due to the functioning of the economy:

1.Keynesian Theory: It focuses on aggregate demand and leaves aside the supply of factors of production. Investments determine the economic cycle, and investments depend on aggregate demand. State expenditure stimulates aggregate demand. The free market is imperfect.

2.Monetarist theory: It focuses on aggregate supply. The average production level is independent of aggregate demand. Economic policies are limited in effect. The market is perfect. Predictability and stability are needed. Monetary policy has a short-term effect

3.New classical macroeconomics and real business cycle theory: It focuses only on aggregate supply. Markets are efficient, they are always adjusted. Agents are rational and have rational expectations. Prices and wages are flexible. Macroeconomic policies are irrelevant. Economic cycles are due to technological shocks and due to the maximization of the intertemporal utility.

4.Neo Keynesian theory: The market is imperfect. Prices and wages are rigid, competition is imperfect. Macroeconomic policies are effective, they make prices more flexible. Agent's optimism is important, agent's expectations influence the market.

5.Austrian School: The economic cycle appears due to lax monetary policy and the artificial expansion of credit that lowers the interest rate below the market price. There are massive erroneous investments, which consumes limited resources, in unnecessary production processes. Due to credit expansion, there are resource transfers to industries not required on the market 
6.Mainstream Theory: The interaction between aggregate demand and aggregate supply gives aggregate output. The production trend is given by the offer. Short-term fluctuations around the average output are due to aggregate demand. Macroeconomic policies stabilize economic fluctuations. Monetary policy influences production in the short term. Wages and prices are rigid, they are flexible by monetary policy. The expectations of the agents influence the course of the economy.

\section{Literature review}

\section{Exogenous theories of economic cycles}

These theories explain the emergence and formation of economic cycles through forceful actions outside of the economic phenomenon.

Historian Ian Morris speaks of the existence of five knights of the apocalypse: the first knight is climate change which leads to the second and third, famine and diseases, followed by the fourth, migrations of aggressive peoples that put pressure on the organizational structure and finally the last Knight the fall of the state.

Historian Jared Diamond describes five elements that lead to disasters: climate change, hostile neighbors, collapse of key trading partners, environmental issues, and society's response to the four factors mentioned. Influenced by Malthus, however, he sees in overpopulation more precisely in the depletion of resources compared to the population the major problem of a civilization.

Various authors take the forefront of political factors such as: demographic waves and migrations; finding new natural resources; wars; revolutions; radical institutional changes; election expenses.

\section{The Kitchin cycle}

There are short 40-year cycles discovered in 1920 by the economist who gave the names of cycles. This cycle occurs due to the time between getting, producing an event or cumulating events, transmitting information related to that event, getting information to decision makers, making a decision, and passing the decision, if necessary, the necessary back-up.

\section{The Juglar Cycle}

It is a cycle due to 7 to 11 year investments identified in 1862 by a French economist who gave the name of this type of cycle. Capital goods have a certain amount of life, which can be used to produce goods efficiently with low costs and benefits obtained after the sale of the goods.

Replacement of capital goods requires massive investments in short time that can only be covered gradually over time. Investments for the replacement of capital goods require a prior saving. The time between the emergence of the need to replace the old capital goods as they begin to produce inefficiency and the time of maximum capacity production of the new capital goods may fall to the recession.

\section{The Kuznets cycle}

It is an economic fluctuation with an average life of 15 to 25 years identified in 1930 by Simon Kuznets. These economic variations are linked to migratory waves, demographic processes. With population inflows into a certain area or population growth through internal processes, there is a need for investment in construction and infrastructure. 
This type of cycle is linked to variations in land prices, which can be avoided by different taxes.

\section{The Kondratiev cycle}

Russian economist Nikolai Kondratiev highlighted the 40 to 60-year long cycles in his major Economic Cycles. Kondratiev has identified three phases of the cycle: expansion, stagnation, recession. In the third decade of the twentieth century Kondratiev recognized three cycles in the 19th century: 1790-1849 with a turning point in 1815; 1850-1896 with a turning point in 1873; and a new cycle starting with 1896.

The causes studied by the Russian economist include inequality, opportunities and social freedoms. The effects of these causes affect: technological progress, demographics, political stability. If there is low inequality, then there are many opportunities, technical progress, there is an intellectual and entrepreneurial fervor. If there are major inequalities between the rich and the poor then the rich will block all opportunities in order to preserve their privileges and there will be stagnation, revolutions and wars. It is necessary in the light of this theory of a distribution model to create social peace.

Business opportunities lead to new improvements and scientific and technical breakthroughs that will trigger a technological and productive revolution, creating new productive sectors within the economy.

\section{Endogenous theories}

\section{Keynesian theory and economic cycle (Keynes, Samuelson, Hicks)}

This theory emphasizes the role of aggregate demand in determining the amount of investment and implicitly in the phases of the economic cycle.

For Keynes, the will to act is important, in front this will, the economic laws are fading. When collective will languishes, the state, an embodiment of the economic god, must fill the lack of vitality. In order to get out of the crisis, it is necessary: to increase the budget deficit of the state for carrying out public works; tax reductions; transfer payments to the needy.

This economist believes that capitalism can not ensure full employment because it can not coordinate the spending plans of all participants. The intuitive finding that the balance on each individual market of each good / service would balance all markets is wrong. In order to achieve the balance, it is necessary once and for all to have all the goods or services. But the emergence of new creations or new improvements can not be coordinated.

Putting emphasis on spending, Keynesians see a problem of the economy on the lack of coordination between spending and investment. If at one point people cut their spending for various reasons, the economy is declining with falling incomes, employment, wages. If investors knew what kind of products people would spend in the future, then they would support the investments in those products. If uncertainty blocks the economy, only the state can reduce the uncertainty.

Problems in Keynesian vision: in industries with long-term productive processes, entrepreneurs may refuse to invest because they can not know in advance the demand for the resulting products. Only if the demand for products complementary to those resulting from the long-term productive processes could be anticipated then there would be demand-offer coordination.

Keynes notes that even in the case of floods with liquidity in the market, consumption may not increase as money will be kept as a necessary measure for an unanticipated future and in which buying power is needed. The flooding of the liquidity 
market is given by the interest limit 0 . However, the limit 0 can not be kept because it would shift from deposits to cash.

\section{Monetaryist theory and economic cycle (Friedman, Phelps, Laidler)}

For economist Milton Friedman the creator of this theory, the money supply is the problem. An inadequate offer of money leads to the crisis. Reducing money supply leads to declining aggregate demand and at the same time reducing bank deposits and bank reserves leads to lower supply of money. It is therefore necessary to reduce the interest rate applied by the central bank, and the central bank must be a lender of last resort.

Monetarism refers to the macroeconomic effects of money supply and focuses on central bank action. Friedman recommends that monetary authorities focus on price stability and not trigger inflation through expansionist policies. For the Chicago School led by Friedman, monetary policy is important, money matters, the demand for money is very stable.

An increase in money supply over the need for a balanced balance of agents leads to higher spending, reducing money supply generates a reduction in spending. Monetarism appears as a reaction to high unemployment and high inflation in the eighth decade of the last century.

In short, economic cycles are created by the irrational growth of money supply; monetary shocks affect aggregate demand that change in worse production and employment. Friedman found historical evidence in the American economy to support his claim.

In the long run, the supply of goods and services is determined by the real factors: the quantity and quality of the workforce, the capital goods stock, the infrastructure, the natural resources, the technological state.

Around the Keynesians' conception, the decline in the supply of money by the Central Bank leads to a decline in aggregate demand, prices will fall, followed by a reduction in output adjustment to diminished demand, which leads to implacable unemployment, and lower employment in the economy. Partial wage rigidity will cause unemployment until salary adjust to the new production and the new prices.

Briefly, by reducing the money supply, recession is entering. Salaries are to adjust to the new offer at a slow rate due to partial rigidity, prices are also adjusted and a new balance appears at a lower level of prices and wages.. Monetarists to explain price level changes assume that real national income remains constant at potential GDP or total occupancy.

To explain the expansion is supposed a sudden increase in the amount of money or increased rates of growth of the stock of money in the market. As explained above, there is an increase in aggregate demand and consumption, prices are presumed to be partially rigid. So there is an anticipation of future profits from agents and this leads to higher investment levels, demand for investment leads to higher wages, and prices will adjust upward to consumption. A new balance is achieved at wage levels and high prices.

On short-term fluctuations are a problem and a result of how money is changing in the market; the money supply has a destabilizing effect on the economy, and the cycle revolves around the level of employment. In the long run, the economy is automatically returning to employment balance to potential GDP.

\section{Classical macroeconomic theory and economic cycle (Lucas, Barro, Kydland)}

People are rational, they say in this theory and they make forecasts by analyzing the information they consider relevant and available, information on price levels and that 
containes data on monetary policy namely inflation, fiscal policy, ie budget deficit, import prices of raw materials, capital goods, etc. The theory asserts that agents learn by experience to anticipate economic events; the information that agents can concatenate can only be imperfect; agents act immediately to protect their interests; markets are perfect, and prices and wages are flexible.

The economic cycle, result from unpredictable dynamism linked to aggregate demand. If demand grows unanticipated implicitly will increase production and employment, demand reduction will have reversed effects. In light of this theory, it is important to study the factors that influence and determine aggregate demand. Unanticipated changes in the money supply, acceleration of budget expenditures and the creation of a strong budget deficit, upward or downward changes in taxes, the emergence of new taxes, unexpected changes in interest rate, changes in unpredicted international price markets, technological change .

If agents in the market predict the change in aggregate demand roughly correctly then wage and price adjustments will be made to remain in a relative balance. Market agents collect information and based on available data analyzes, estimates of change in money supply take place and certain expectations are formed. If wages and prices are flexible and will change as forecasts.

If there is an increase in aggregate demand as an increase in the stock market money is forecast, it will not affect production and employment. Wages and prices go up as an increase in the money supply is expected. Only if there is a change in the upward trend completely unexpected in the money supply there are upward changes in production and employment.

If there is an unanticipated decline in aggregate demand due to an unexpected drop in the supply, a heavy tax, or a fall in demand for exported goods then the wage rate will not change shortly due to the unpredictability event. As a result of the unexpected decrease in aggregate demand, there is a fall in aggregate output and the unemployment appears due to wage rigidity.

After the first shock, anticipations are made. If declining aggregate demand and falling prices following the fall in demand are forecasted, wage negotiations and wage cuts will follow to maintain the proportionality of real wages - production so as to avoid an increase in unemployment. Unemployment will only occur if GDP falls below the total occupation.

An unexpected increase in global demand is driven by a surprising surge in supply, by drastically and unexpectedly reduced taxes, by high demand for exported products through technological change. Because demand is rising unexpectedly, wages do not change, instead, prices increase, production and, implicitly, GDP. Along with production, employment will increase, unemployment will fall below its natural level. There will be a new balance once salaries grow and adjust to the new monetary supply and agents are making anticipations close to the upcoming reality.

\section{Theory of real business cycle and economic fluctuations (Prescott, Long, Plosser)}

The theory asserts that the nominal variables of the economy, namely money and, implicitly, monetary policy do not influence the real economy, only the real variables change the real economy ie the fiscal policy and the technological innovations.

The theory affirms that prices are flexible and price levels adjust to balance the money market, so the money market is ignored by just looking at real variables, ie output and the real interest rate. The mathematical model of the theory indicates that the production of goods and services depends on accessibility to the factors of production and 
the availability of technology. Actual aggregate demand for goods and services and real aggregate supply is a function of the real interest rate. In this mathematical model the price level is unimportant, the theory is only interested in the real economic variables.

The theory stops with the analysis of changing the level of employment during the economic cycle. The aggregate income depends on fluctuations in labor supply, and in turn output depends on the amount of labor in the market, the more people are willing to work more, the more output. Therefore, it is necessary to analyze the factors that influence labor supply and aggregate income.

A new technology determines the increase in investment but at a rate that is decreasing over time; they produce outputs through the extensive production process initially then grow but with a decreasing rate until stabilization, thus creating a new balance. Production grows for a while and after investments stop.

Regressions in this theory arise due to technological deterioration that reduces labor productivity per worker and reduces total production, thus reducing labor incentives. The theorists adhering to this theory mark the equation between technological shocks and climate change or finding / exhausting new natural resources. Economic cycles are open to the frequency and magnitude of those items.

Money is neutral in the sense of this theory, which means that monetary policy does not affect production and employment. The increase in the supply of money is a result of a technologically beneficial shock, the increase in money supply is necessary to cover a growing demand as a result of a large amount of goods and services.

Prices and wages are elastic and are quickly adjusted to the perfect markets to match demand with supply. Perfect markets best allocate resources under the guidance of a perfect knife.

The economic cycle is a natural adjustment of the market to technological change and the government's fiscal policies have a limited and even damaging economy stabilization capacity.

\section{Neo Keynesian theory and economic cycles (Stiglitz, Krugman, Mankiw)}

Keynesian theorists build their discourse around the rigidity of wages and prices, those are hard to adjust to the new macroeconomic conditions, so that unemployment and short-term production fluctuations occur.

Reasons for the rigidity of wages and prices:

Cost of changing prices. If aggregate demand changes then it would be necessary to keep the workforce employed, to change the prices of the products, but this does not happen in the real economy. Adjustments are made by companies at regular intervals due to the costs associated with changing prices. There is also a phenomenon of managerial inertia to changes in macroeconomic conditions. Price adjustments are made discreetly, in steps rather than continuously and instantaneously.

Outsourcing the demand. Economists also draw attention to external effects on price adjustment. If a single company reduces prices, this has positive effects on other companies that use that product. The reduction in the price of one company leads to a marginal decrease in the average price level. In case of economic expansion and aggregate demand growth, the price adjustment by a firm changes the demand for all products of other firms.

Lack of coordination. Another key element in the vision of new followers of Keynesian theory is the lack of coordination of agents in the event of a recession. In the case of economic growth there is a good allocation of resources. Lack of coordinating agents in the market to establish price and wage levels will certainly lead to inefficiency 
in resource allocation. Market agents fail to anticipate the movements of other players, and there is a lack of synchronized behavior in the economy. Firms need to keep up-todate on what prices will be set by other companies in the market, so they can adjust their movements in advance.

Even though price rigidity is harmful to everyone, they remain so because all agents expect it. The number of companies is high, so effective coordination is difficult, especially when all of them have price rigidity forecasts. There is actually a coordination problem. Changes in prices and salaries do not appear simultaneously but gradually, staggered. Even if individual changes occur frequently, total changes occur slowly.

The insider-outsider model. Employees unionized within an enterprise are the only ones who really have the power to negotiate on wages. They will not demand a salary cut so that other outside workers can get involved. Outside workers are irrelevant in the wage bargaining process. Always trade unions bring wages above the equilibrium level, leading to the permanent existence of a group of unemployed workers. As long as the contracts are fixed and the expectations regarding the future income do not change, there will always be unemployment.

There would be no recession if a reduction in aggregate demand, the market acted in a coordinated manner, and prices and wages declined by the same percentage. There is stuttering because the first who acts, will lose if he makes the wrongful assessments of the economic situation, and the other agents in the market do not act. In brief, the information is asymmetric and there is imperfect competition. The quantity produced by agents in the Neokeynesian vision depends on prices, prices that the analytical concept of economists concentrates on. So prices determine the quantities produced.

\section{Austrian School and Economic Cycle Theory (Menger, Mises, Rothbard, Hayek)}

The main idea of this school is that the actual functioning of the monetary system itself creates superinvestments in the economy, more accurately said erroneous investments.

When there is a balance in the economy there is a certain optimal ratio between the production of consumer goods and the capital goods. There is some equivalence between the mentioned report and the ratio between the demand for money for savings and consumption. The resources distributed between capital goods and consumer goods are in the same proportion as money between saving and consumption.

With the expansion of the money supply and with the decline in bank interest below the market rate, there will be a leak of money to the capital goods investment system, artificially provoking a prolongation of the production process. The mistake lies in the failure of the monetary system to maintain a neutral monetary supply.

In the Austrian paradigm cycles are due to unjustified credit expansion by reducing the interest rate below market level. Banks use deposits with partial coverage and emit unattended fiduciary currency in real saving of the population. Scriptural currency issued does not cover neither in precious metal deposits nor consumer goods or capital. The fiduciary currency is not a reflection of abstinence from consumption but it is just an illusion of the wealth maintained by the monopoly holder of the exchange of money, an illusion introduced into the economy on certain channels favored and enriched on the account of others.

Stages of crisis: Expansion of credits by lowering the level of interest rates below the level established by the market. It does not take into account the temporary preference of the population who prefer to consume but save and prefer consumer goods easily obtained without capital intensive investment. 
Investors are misled by market signals and decode these signals erroneously. It gives the impression by lowering interest that people have a less time-consuming preference to save.

So, investment projects that were not feasible earlier because their end product costs higher than the market price are now profitable. Agents buy capital goods for investment. Capital asset prices are rising.

The big problem of the economy appears: limited resources. The same resources are required by the capital goods and investment market and the consumer goods market. Prices rise on both markets at the level of demand, supply and real resources. There are not enough resources to finalize all the started investment projects and to meet the consumer demand for consumer goods. In order to realize the investments started, resources must be released through saving, abstaining from consumption. But saving is not done because of the time preference of the population.

By expanding the credit there is an extraction of resources held and their directing to capital goods over consumer goods. When the initial injection of liquidity ceases the consumption goods prices explode according to the preference of time.

\section{Methodology}

The desired knowledge in this essay is an "a priori" one, provided by "praxeology", meaning knowledge independent of sensory experience, knowledge that applies universally with a necessary character.

We are the followers of a methodological dualism, ie the application of logical positivism in the natural sciences, and praxeological method in social sciences. The categories of praxeology are obtained by logical analysis of the category of human action and other obvious axioms. Judgments are analytical and deductive, ie we extract from the axiom the notions included and contained in advance. Axioma can not be derived empirically because actions can not be perceived in itself.

Apriorism, praxeological, can be understood in two ways. Forms, essences of the human mind imposed on the world and forms, the essences of the world captured by the human mind. In the first case, judgments are relations between concepts, that is, analytical judgments; in the second case, they are judgments between the essences of nature independent of the human mind, namely synthetic judgments. We want to use both types of judgments. Certainly, between the forms of the human mind and the world, there is a relationship of correspondence, otherwise the world would be unintelligible, unusable, or man would not belong to this world and could not live in it.

Only in relation to human attitudes and intentions objects exist as economic objects, that is, how man is referring to them according to purpose.

In social sciences, positivist empiricism can not be applied because human action can not be reduced to the physiological level. Experiment and observation in social sciences can not be reduced. In the social sciences, many elements that interact closely must be considered, many of those elements that are involved are unknown. Empirical tests in social sciences are irrelevant.

\section{Conclusion and further developments}

If the economic crisis in the European Union occurs and this is led by: 
Keynesians, then the state must actively engage in fiscal spending policies to overcome aggregate poor demand and ensure a high degree of investment and employment in the labor market.

Monetarists, then the state must use predictable policies and stabilize the economy by ensuring central bank independence and promoting clear monetary policy rules. The state should not get involved in the market or cause inflation. Monetary policy is important, and in the event of an economic crisis a slight monetary easing is required.

Adherents of classical macroeconomics and RBCs, then the state must not intervene in the market, markets need to be streamlined, wages and prices must be made more flexible, reduced the role of trade unions and any coergitive interference on the market

Neo Keynesians, then the state must intervene forcefully on the market through regulations, aggressive fiscal and monetary policies. The financial system must be regulated and controlled. Central banks have the role of a lender of last resort and must provide the necessary liquidity, the central bank must also act as a buyer of last resort assets. The state needs to ensure through aggregate spending the aggregate demand needed to keep the investment from falling.

Mainstream enthusiasts are willing to use any method that appears in economic literature regardless of theory to ensure economic stability in the short term without taking into account long-term negative effects.

Austrians, then the state must withdraw from the economy, and the state would only provide the legislative framework for the fulfillment of the existing contractual relations on the market, voluntarily accepted by the contractors. The concept of private property would have to extend to its last consequences, the notion of public property would be diminished until extinction. The central banks would close down and return to $100 \%$ reserve banking and return to gold currency, possibly silver. The European Union would become a union of landowners who would act only on a voluntary basis without affecting other properties.

In order to cope with a major economic crisis, the European Union should be primarily a political union. Monetary Union in the event of a crisis only deepens the recession in some countries at the expense of others.

The difference in economic development between the European countries makes a monetary union to deepen the problems instead of solving them. The lifting of legal barriers to labor migration does not solve the problem, there are cultural barriers and language differences that make workers' migration between European countries to be limited. Workers simply want to work in the countries where they were born, and capital mobility is short-lived and due to differences in legislation.

In the event of a crisis, a way to mitigate the negative effects was monetary policy, a policy that could sweeten the bitter pile of the crisis. At the time of the euro adoption, the possibilities to use monetary policy have disappeared. Some industries are not so performing as to be able to cope with a tight monetary policy, the dismantling of customs barriers, and the competition of more developed countries. The Germans were able to 
save while others were borrowing to spend to sustain their savings. The problem is that in the event of a crisis, the loan is canceled if the debtor can not pay.

The politicians in each country in the event of a crisis will try to solve the problem of the citizens they depend on, while at the same time the bureaucracy within the U.E. is too distant and indifferent to act.

Separate fiscal policies on each country can not solve problems, costs need to be reimbursed, the only thing that is being done is a delay in solving problems.

The only viable alternative would be the transformation of the European Union into a union of owners and the withdrawal of the state from economic activity. Certainly each individual owner will know best how to enter into contractual relationships.

\section{References}

Altug, G. Sumru "Business Cycles. Fact, Fallacy and Fantasy” World Scientific Publishing, 2010.

Borio, Claudio “ The Financial Cycle and Macroeconomics: What Have We learnt?”, BIS Working Papers No. 395 december 2012.

Diebold, X Francis, Rudebusch, D. Glenn, "Business Cycles. Durations, Dynamics and Forecasting", Princeton University Press, 1999.

Friedman, Milton, Schwartz, J. Anna "Monetary History of the United States 1867-1960", Princeton University Press, 1963.

Friedman, Milton. (1963), "Inflation: Causes and Consequences”, Asia Publishing House, New York.

Huerto de Soto, J.,2006 „Money, Bank Credit and Economic Cycles” Auburn, Ala.:Ludwig von Mises Institute.

Krugman, P. R. \& Torsten Persson \& Lars E.O. Svensson, (1982). "Inflation, Interest Rates, and Welfare," The Quarterly Journal of Economics, MIT Press, vol. 100(3), pages 677-95, August.

-Kydland, E. Finn, Prescott, C. Edward "Time to Build and Aggregate Fluctuations", Journal of the Econometric Society, 50, 6, November 1982.

Kiyotaki, Nabuhiro "A perspective on Modern Business Cycle Theory”, Federal Reserve Bank of Richmond, Economic Quarterly, Vol. 97, No. 3, 2011.

Keynes, John Maynard, "The General Theory of Employment, Interest, and Money", MacMillan and Co., London, 1936.

Long, B. John, Plosser, I. Charles "Real Business Cycles", Journal of Political Economy, 91, (1), february 1983.

Lucas, R.E. (1972) "Expectations and the Neutrality of Money". Journal of Economic Theory, 4 (2), 103-24. Reprinted in Lucas, 1981.

Lutz, G. Arnold "Business Cycle Theory", Oxford University Press, 2002.

Mises, L. v. (1966) "Human Action, A Treatise on Economics”, 3rd ed., Chicago: Henry Regnery, pp. 408-416.

Stiglitz, J., (1988) "Imperfect Information, Credit Markets and Unemployment", NBER Working Papers 2093, National Bureau of Economic Research, Inc.

Samuelson, P. A. and all (including Friedman, M.) (1952) "Monetary Policy to Combat Inflation", The American Economic Review, 42, 3 (Jun., 1952), 384-391. 